\title{
EDITORIAL
}

\section{Em busca de novos tempos}

A Editora da Universidade Federal Fluminense, ou simplesmente EdUFF, chega a novos tempos, neste final de milênio, quando se apregoa o fim da galáxia de Gutemberg e o nascimento da disseminadora e, muitas vezes, múltipla Constelação Cibernética. Ela vive novos desafios, sem abdicar da tradição antiga que sempre nos levou a ver, no livro impresso, a fonte principal de disseminação do saber. Nessa dobradiça temporal, é preciso buscar o fiel da balança e saber harmonizar tradição e transformação, tentando encontrar o lugar simbólico onde o velho e o novo se entrecruzem e se retroalimentem.

Pensando nisso e vendo ainda a Editora como uma espécie de mão dupla, que tanto projeta a nossa comunidade acadêmica para fora, quanto introjeta o que o meio onde nos inserimos produz, chegamos a algumas linhas de ação que nortearão nosso trabalho nos próximos anos:

- publicação de obras de reconhecida qualidade científica que venham ao encontro das expectativas e necessidades das diversas áreas do saber;

- incentivo a co-edições elou parcerias com organismos elou instituições internos ou externos;

- criação de um programa de traduções, para democratizar o acesso ao saber científico no país;

- edição de textos didáticos elou paradidáticos que possam dar suporte ao ensino, em seus vários niveis.

Para além disso, manteremos séries já existentes, como Estudos e Pesquisas, propondo a criação de outras, como Aprendendo e Ensinando, por exemplo, continuando a apoiar as coleções de responsabilidade dos órgãos colegiados, departamentos, programas de pós-graduação etc.

Sabemos ser este um tímido passo, mas é o que, por ora, temos possibilidade de dar. Se não podemos sonhar mais alto, também nos recusamos a deixar de sonhar. Assim, esperamos galgar patamares, difundir uma produção de qualidade e, principalmente, mostrar a face do que somos, buscando, nos novos tempos que chegam tão rápido, ainda um pouco da utopia que nos faz acreditar no futuro, como promessa. 